\title{
Struktur dan Makna Tarian Yosakoi
}

\author{
Yussy Talitha $\mathbf{K}^{1)}$, Ely Triasih Rahayu ${ }^{2)}$, Muammar Kadafi ${ }^{3)}$ \\ PS Sastra Jepang FIB, Universitas Jenderal Soedirman \\ Purwokerto, Jawa Tengah \\ Email: 1ytalitha8jn98@gmail.com], ${ }^{2}$ ely.rahayu@unsoed.ac.id], \\ 3 [muammar.kadafi@unsoed.ac.id]
}

\begin{abstract}
Abstrak
Tujuan dari penelitian ini adalah untuk mengetahui struktur gerakan dan makna yang terdapat pada tarian yosakoi. Tarian yosakoi merupakan tarian tradisional yang diperkenalkan pertama kali pada tahun 1954 di prefektur Kochi. Tarian kochi yosakoi pertama kali diperlihatkan saat festival musim panas, dengan tarian dasar bernama seicho. Seicho yosakoi ditarikan dengan iringan lagu yosakoi naruko odori dan menggunakan alat musik yang bernama naruko. Selain ada di prefektur Kochi, yosakoi juga berkembang ke daerah Hokkaido. Tari yosakoi di Hokkaido dikenal dengan nama yosakoi soran. Yosakoi soran pertama kali diciptakan oleh Hasegawa Gaku pada tahun 1992. Berbeda dengan kochi yosakoi, yosakoi soran pertama kali diperkenalkan diiringi lagu tradisional soran bushi. Jenis penelitian ini adalah deskriptif kualitatif. Sumber data penelitian ini berupa gerakan dari penari yosakoi yaitu kelompok Iroha dan Yuujou Taiko. Metode penelitian ini menggunakan studi pustaka, observasi dan wawancara. Teknik analisi data dilakukan dengan menganalisis struktur gerakan dan makna dari tarian seicho dan soran bushi berdasarkan konsep semiotik Roland Barthes. Hasil penelitian ini menunjukkan adanya 5 struktur gerakan dalam tarian seicho yosakoi yang memiliki makna konotasi, dan terdapat 14 struktur gerakan dalam tarian soran bushi. Kesimpulan dari struktur dan makna 2 tarian tersebut adalah hanya memiliki makna konotasi. Pada tarian seicho, memiliki makna ajakan kepada orang-orang untuk datang dan bersenang-senang saat musim panas di festival yosakoi. Sedangkan pada soran bushi, tarian ini memiliki makna menggambarkan bagaimana nelayan pergi melaut untuk mencari ikan.
\end{abstract}

Kata kunci : Yosakoi, Kochi Yosakoi, Yosakoi Soran, Seicho, Soran Bushi

\begin{abstract}
The purpose of this study was to determine the structure and meaning of movements contained in the yosakoi dance. The yosakoi dance is a traditional dance that was first introduced in 1954 in Kochi prefecture. The kochi yosakoi dance was first performed in a summer festival, with the basic dance was called seicho. Seicho yosakoi is danced with the yosakoi naruko odori song and uses a musical instrument called naruko. Besides at Kochi prefecture, yosakoi also has expanded to the Hokkaido area. Yosakoi dance in Hokkaido is known as yosakoi soran. Yosakoi soran was first created by Hasegawa Gaku in 1992. Different from kochi yosakoi, yosakoi soran was first introduced with the traditional song soran bushi. The type of this study was descriptive qualitative. The data source of this study was the movement of yosakoi dancers, namely the Iroha and Yuujou Taiko groups. The method of this study used literature study, observation and interview. The data analysis technique was conducted by analyzing the movement structure and meaning of the seicho and soran bushi dances based on the semiotic concept of Roland Barthes. The results of this study showed that there were 5 movement structures in the seicho yosakoi dance that contained connotative meanings, and there were 14 movement structures in the soran bushi dance. The conclusion from the structure and meaning of these two dances are that they only have connotative meanings. In the seicho dance, it contains the meaning of an invitation for people to come and have fun during the summer at the yosakoi festival. While in soran bushi, this dance has the meaning of describing how fishermen go to sea to catch fish.
\end{abstract}

Keywords : Yosakai, Kochi Yosakai, Yosakai Soran, Seicho, Soran Bushi 


\section{Pendahuluan}

Kesenian tari berkembang sejalan dengan kehidupan manusia. Selama manusia masih mampu bergerak, maka tari akan tercipta dan terus berkembang. Manusia menciptakan tari sesuai dengan ungkapan hidup dan juga merupakan rangkuman gerak yang bersumber dari alam sekitar. Tari merupakan ekspresi jiwa manusia yang diungkapkan dengan gerak ritmis yang indah (Soedarsono, 1986: 24).

Jepang adalah negara yang sangat menghargai dan menjaga kebudayaan yang ada, baik tradisional ataupun modern. Kebudayaan yang ada selalu diajarkan secara turun temurun kepada generasi muda. Budaya Jepang yang beragam, sangat menarik untuk dilihat dan dipelajari. Salah satu kebudayaan Jepang yang mulai dikenal di Indonesia adalah tarian Yosakoi (よさこい). Yosakoi (よさこい) pertama kali dikenalkan pada tahun 1954, masyarakat prefektur Kochi（高知） mengadakan Yosakoi Matsuri （よさこい祭り） untuk mengusir hawa panas dan untuk mengembalikan kondisi di daerah pertokoan Kochi (高知). Tarian ini berkembang sebagai bentuk modern dari tari musim panas Awa Odori (阿波踊り). Yosakoi（よさこい) merupakan tarian dengan ciri khas gerakan tangan dan kaki yang dinamis. Sambil menari, di kedua belah tangan penari membunyikan perkusi dari kayu yang bernama naruko (鹃子). Mulanya, naruko (鳴子) digunakan untuk mengusir burung-burung di sawah, namun kini digunakan sebagai pelengkap tari. Kochi yosakoi memiliki tarian dasar bernama seicho.

Tarian yosakoi juga berkembang ke daerah Hokkaido. Pada tahun 1992 seorang mahasiswa yang bernama Hasegawa Gaku yang melihat tarian kochi yosakoi berpikir untuk memperkenalkan tarian dari Kochi ini ke Hokkaido, namun dengan diiringi musik yang berbeda. Tarian yosakoi di Hokkaido disebut yosakoi soran, yang ditarikan dengan diiringi lagu tradisional yang bernama soran bushi. Soran bushi adalah nyanyian yang sering dinyanyikan oleh para nelayan untuk membangkitkan semangat saat menangkap ikan di laut.

Penulis memilih tarian seicho dan soran bushi sebagai bahan penelitian dengan permasalahan penelitian sebagai berikut:

1) Bagaimana struktur gerakan tarian yosakoi（よさこい) ?

2) Apa makna struktur gerakan tarian yosakoi（よさこい）? 


\section{Metode dan Teori}

\subsection{Metode Penelitian}

Penelitian ini menggunakan metode deskriptif kualitatif. Menurut Nazir (1988), metode deskriptif merupakan suatu metode dalam meneliti status sekelompok manusia, suatu objek, suatu set kondisi, suatu sistem pemiran ataupun suatu kelas peristiwa pada masa sekarang. Tujuannya adalah membuat deskripsi, gambaran, atau lukisan secara sistematis, faktual, dan akurat mengenai fakta-fakta, sifat-sifat serta hubungan antar fenomena yang diselidiki.

Teknik yang dilakukan peneliti untuk memperoleh sumber data yaitu dengan menggunakan teknik simak catat. Peneliti akan menyimak dan menelaah tarian yang menjadi sumber penelitian dan mencatat gerakan-gerakan yang dapat dianalisis menggunakan teori semiotika.

Validasi data dilakukan untuk menguji keabsahan data, maka perlu dilakukan validasi data. Hasil analisis data dilakukan dengan mengkonfirmasi isi dari analisis data kepada Verlinton Waldo selaku pelatih yosakoi di Universitas Jenderal Soedirman dan Ambassador Yosakoi Tahun 2017.

\subsection{Teori}

\section{Semiotika Roland Barthes (1983)}

Semiotika pada dasarnya adalah sebuah studi atas kode-kode, yaitu sistem apa pun yang memungkinkan kita memandang entisitas-entisitas tertentu sebagai tanda-tanda atau sebagai sesuatu yang bermakna (Scholes,1982:ix). Dengan kata lain, segala sesuatu yang bermakna tergantung pada kode. Kita dapat memberi makna terhadap sesuatu berkat adanya sistem pikiran, suatu kode, yang memungkinkan kita untuk dapat melakukannya.

Pendekatan semiotik Roland Barthes secara khusus tertuju pada sejenis tuturan (speech) yang disebut dengan mitos. Menurut Barthes (1983:109), bahasa membutuhkan kondisi tertentu untuk menjadi mitos, yaitu secara semiotis dicirikan oleh hadirnya sebuah tataran signifikasi yang disebut sebagai sistem semiologis tingkat kedua (the second order semiological system).

Roland Barthes adalah penerus pemikiran Saussure. Berbeda dengan Saussure yang menggunakan istilah "penanda" (signifier) dan petanda "signified" gagasan Barthes dikenal dengan “order of signification”, mencakup denotasi (makna sebenarnya sesuai 
kamus) dan konotasi (makna ganda yang lahir dari pengalaman kultural dan personal). Di sinilah titik perbedaan Saussure dan Barthes meskipun Barthes tetap mempergunakan istilah signifier-signified yang diusung Saussure. Secara singkat kajian semiotika Roland Barthes dapat dijabarkan sebagai berikut :

a. Denotasi

Denotasi merupakan makna eksplisit, langsung, dan pasti.

b. Konotasi

Konotasi merupakan makna yang tidak eksplisit, tidak langsung, dan tidak pasti.

Bagan 1.

Pemetaan Semiotika Roland Barthes

\begin{tabular}{|c|c|c|}
\hline $\begin{array}{ll}\text { 1. } & \text { Signifier } \\
& \text { (Penanda) }\end{array}$ & $\begin{array}{ll}\text { 2. } & \text { Signified } \\
& \text { (Petanda) }\end{array}$ & \\
\hline \multicolumn{2}{|c|}{$\begin{array}{l}\text { 3. Denotative Sign } \\
\text { (Tanda denotatif) }\end{array}$} & \\
\hline \multicolumn{2}{|c|}{$\begin{array}{l}\text { 4. Connotative Signifier } \\
\text { (Penanda konotatif) }\end{array}$} & $\begin{array}{c}\text { 5. Connotative Signified } \\
\text { (Petanda konotatif) }\end{array}$ \\
\hline
\end{tabular}

Dapat dipahami bahwa makna denotasi terikat akan keberadaan penanda dan petanda. Begitupun makna konotasi tergantung akan tanda denotasi.

Di dalam semiologi Barthes konotasi identik dengan operasi ideologi, yang disebutnya sebagai mitos dan berfungsi untuk mengungkapkan dan memberikan pembenaran bagi nilai-nilai dominan yang berlaku dalam suatu periode tertentu. Di dalam mitos juga terdapat pola tiga dimensi penanda, petanda, dan tanda. Mitos adalah suatu sistem komunikasi, bahwa mitos adalah suatu pesan. Mungkin mitos tidak dipahami sebagai suatu objek, konsep atau gagasan; mitos merupakan mode pertandaan ( $a$ mode of signification), suatu bentuk (a form). 


\section{Hasil dan Pembahasan}

Tarian seicho berasal dari prefektur Kochi （高知）, yang terletak di wilayah Shikoku （四国）. Tarian ini dimulai pada tahun 1954 untuk mengatasi ekonomi di daerah perdagangan pasca perang dunia ke II. Di awal diselenggarakannya festival, terdapat 750 orang yang ikut berpartisipasi dan semakin meningkat setiap tahunnya. Para penari menarikan tarian seicho （正調） di sepanjang jalan. Tarian ini diiringi dengan lagu tradisional yaitu “Yosakoi Naruko Odori”（よさこい鳴子踊り）.

Tarian yosakoi soran pertama kali diperlihatkan di bulan Juni tahun 1992 di Sapporo, Hokkaido. Tarian ini menggunakan lagu daerah yang berjudul soran bushi. Tarian dari yosakoi soran menceritakan tentang nelayan.

Penelitian ini berfokus pada dua hal, yaitu menjelaskan mengenai struktur gerakan dan pemaknaannya. Struktur gerakan dan pemaknaan. Hal ini akan mempermudah para pembaca dalam mensinkronkan antara gerakan dan makna, maka penulis akan menggunakan tabel dengan 2 kolom, yaitu kolom petanda (menjelaskan struktur gerakan tarian yosakoi) dan kolom penanda (pemaknaan dari masing-masing gerakan pada kolom petanda)

\subsection{Struktur Gerakan dan Makna Tarian Seicho dari Kochi Yosakoi}

Tarian yang berdurasi 2 menit 58 detik ini memiliki gerakan tangan dan kaki yang dinamis. Terdiri dari 4 atau 5 set tarian yang diulang dengan lirik yang berbeda. Setiap lirik dalam lagu Yosakoi Naruko Odori menggambarkan bagaimana kearifan lokal di kota Kochi, maka tarian Seicho ini juga menyampaikan nuansa yang ada di lagu ke dalam sebuah gerakan.

Berikut ini peneliti akan mendeskripsikan bentuk analisis semiotika Roland Barthes pada tarian Seicho（正調）.

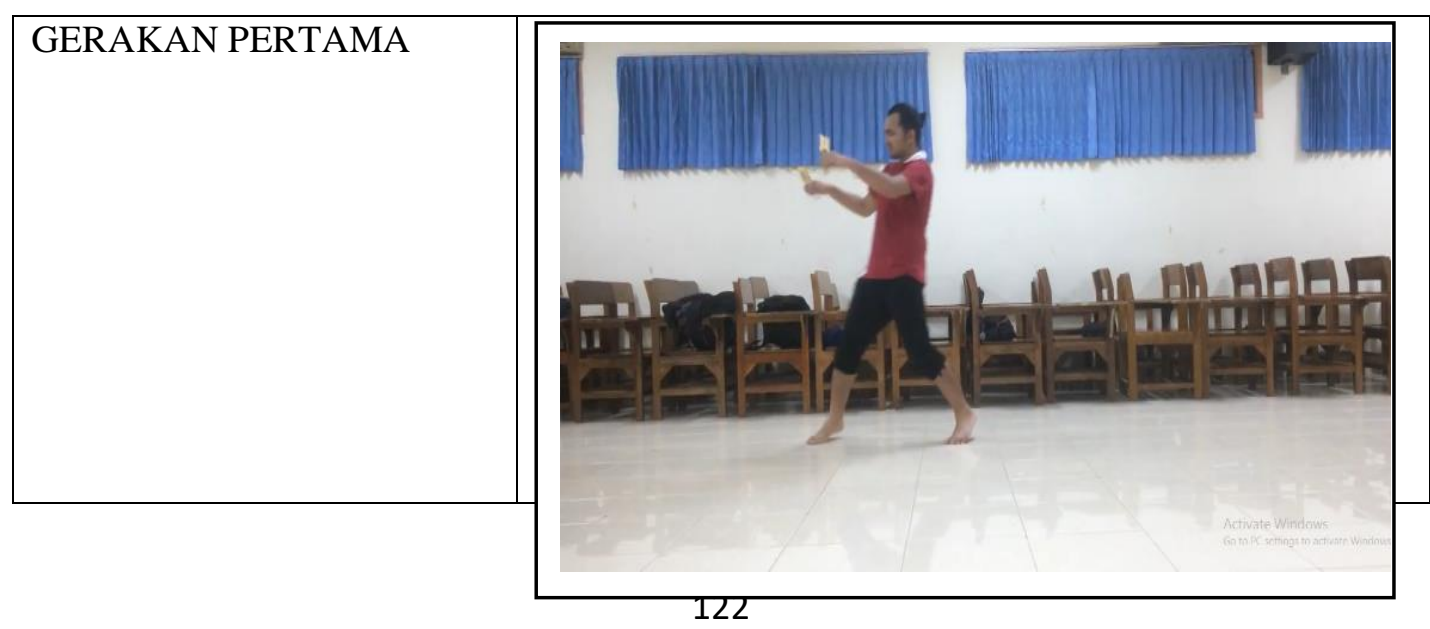




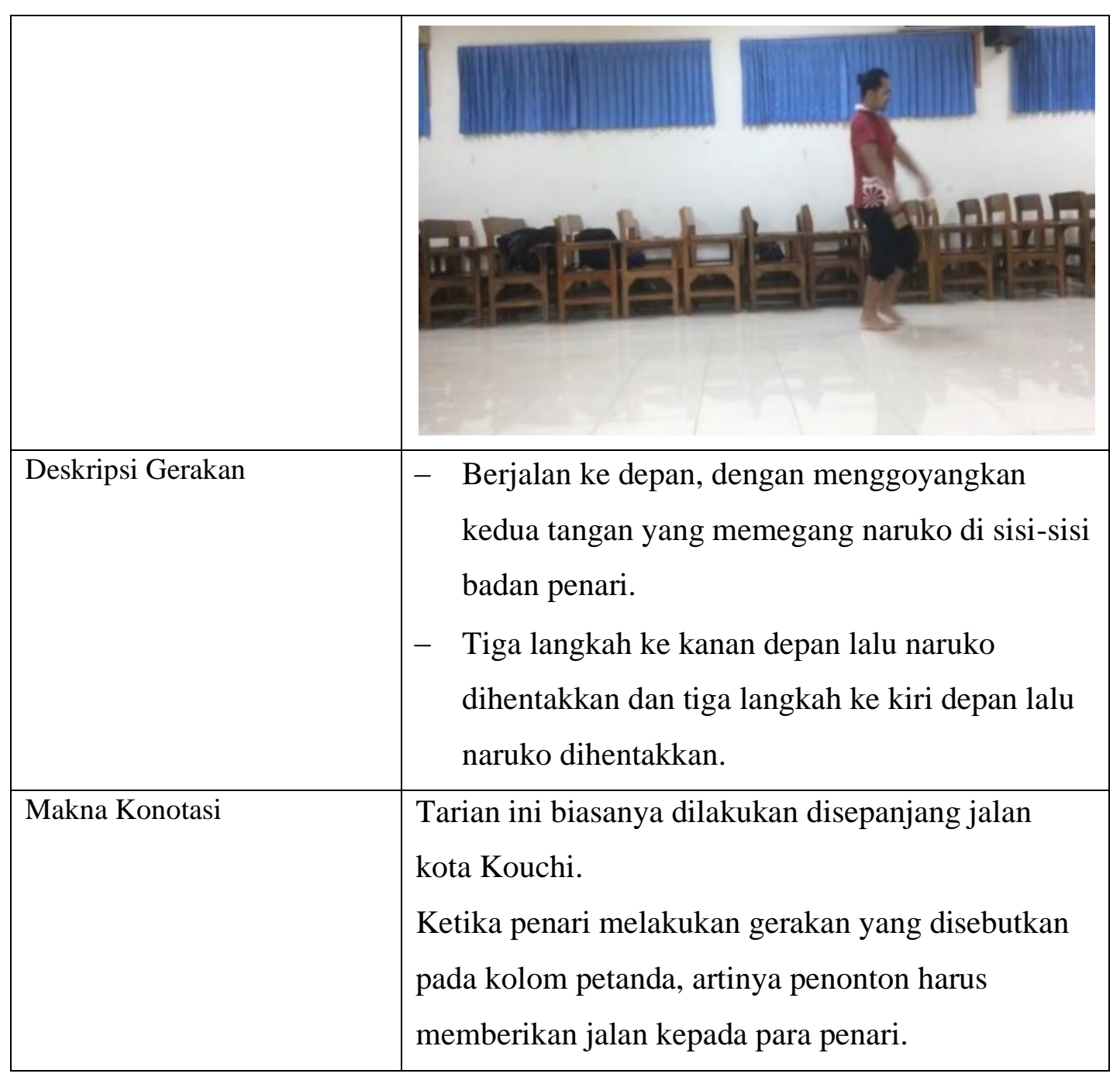




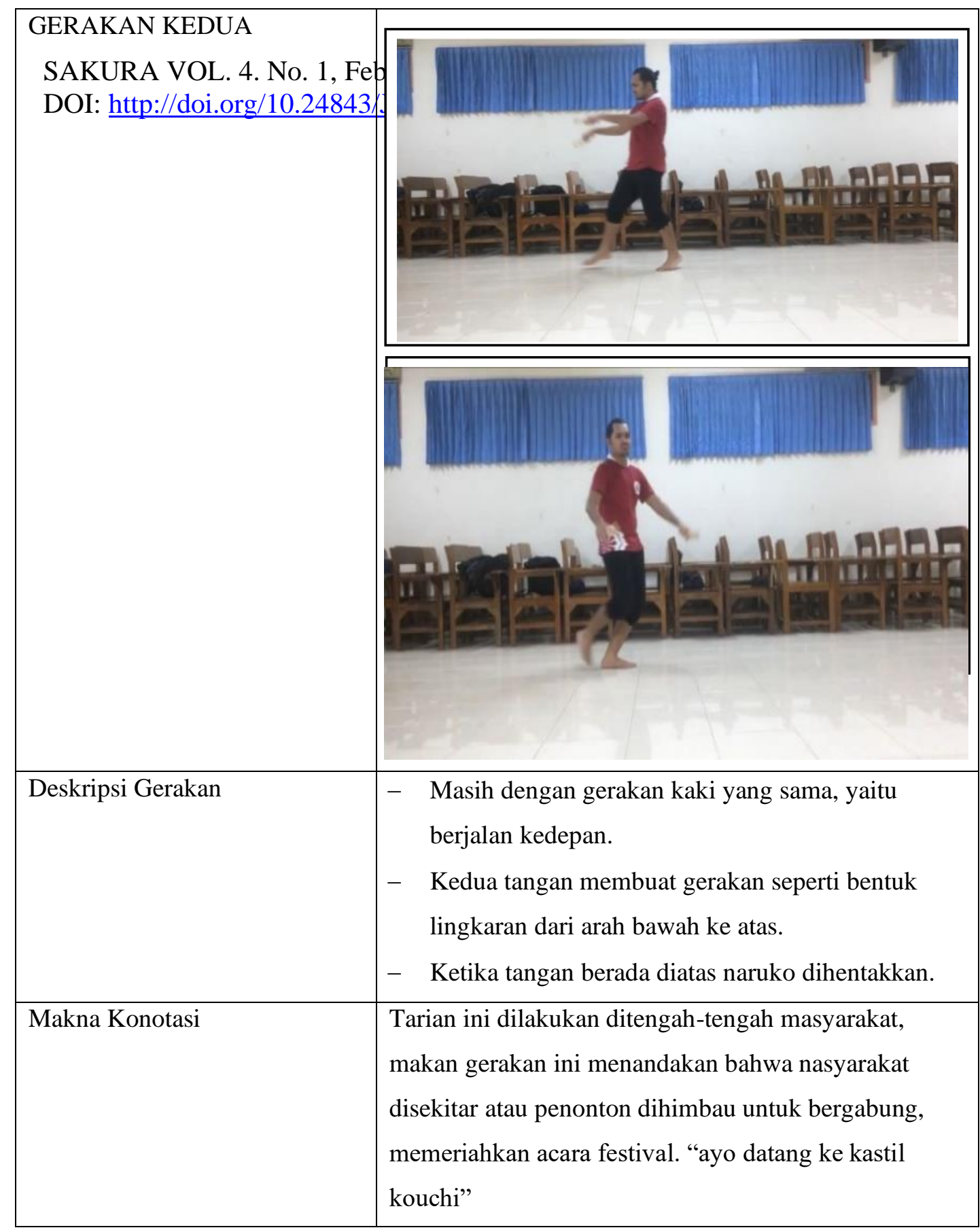

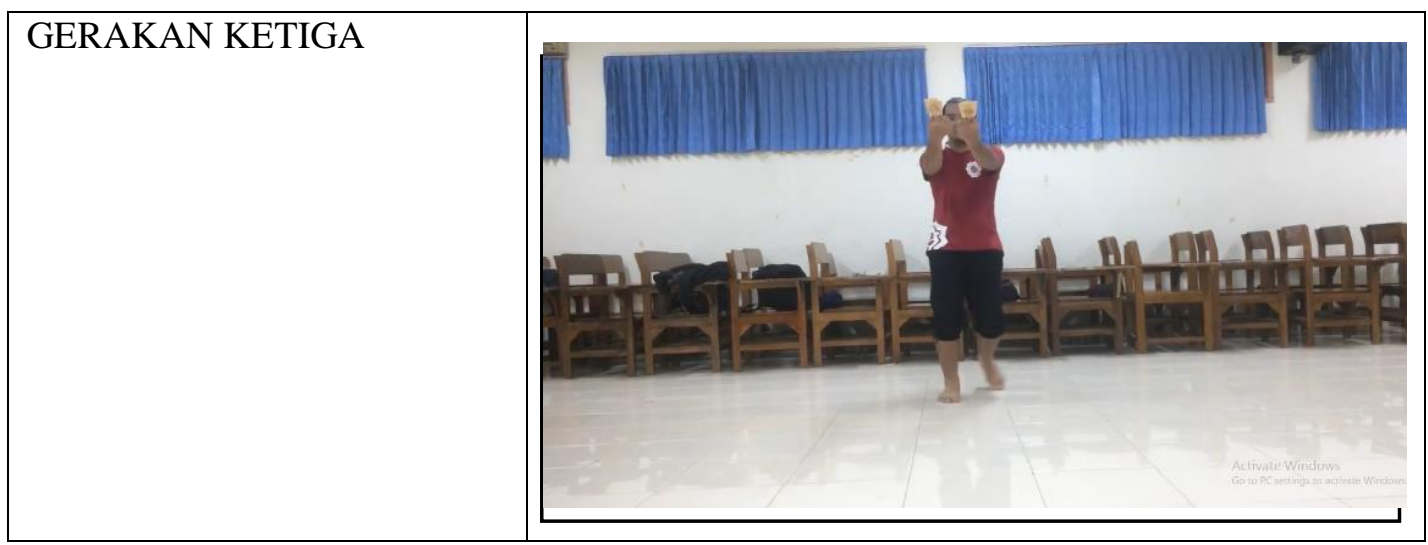




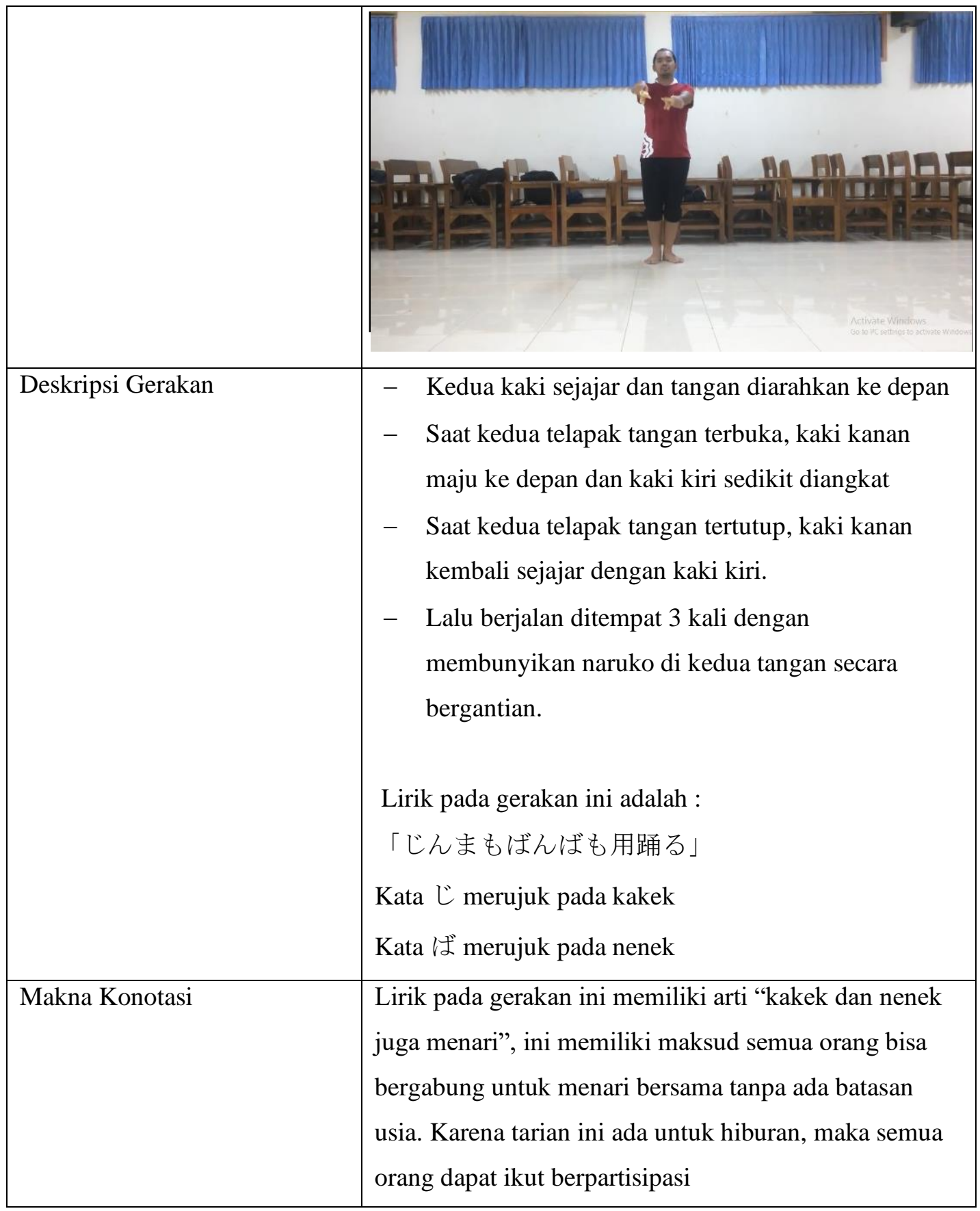

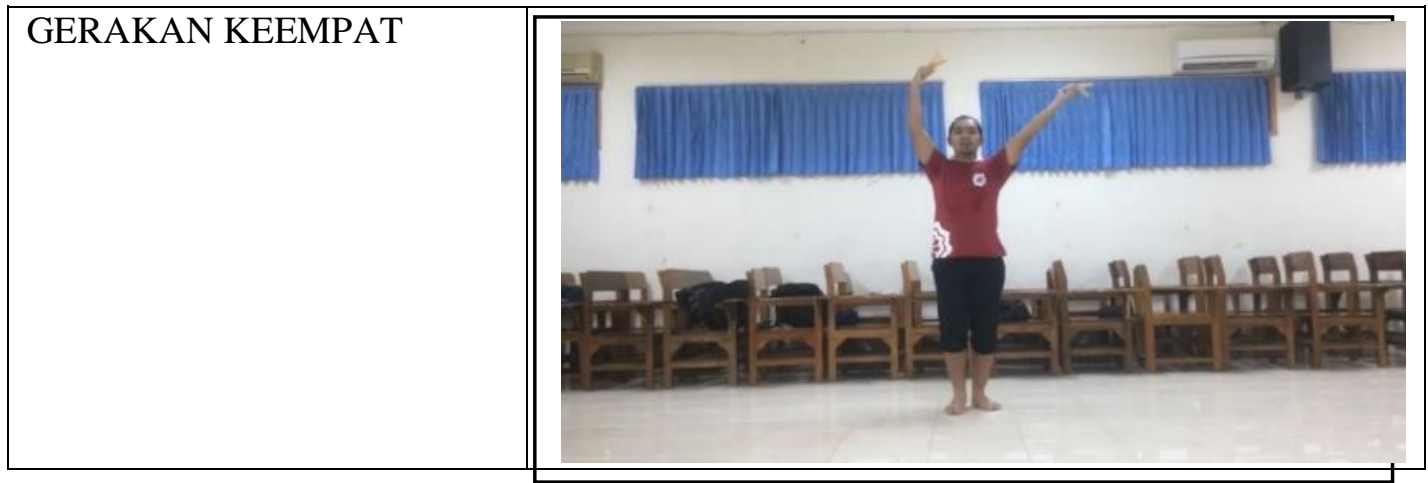




\begin{tabular}{|l|l|}
\hline & \\
\hline Deskripsi Gerakan & - Kedua tangan diangkat keatas, lalu diayunkan ke \\
\hline kakna Konotasi & $-\quad$ Kedua kaki berjalan ditempat \\
\hline $\begin{array}{l}\text { Gerakan ini dilakukan dengan lembut, seperti padi-padi } \\
\text { di sawah yang tertiup angin. Pada lirik terdapat } \\
\text { penyebutan tempat, yaitu jembatan Harimaya, yang } \\
\text { terkenal sebagai tempat diselenggarakan festival } \\
\text { yosakoi di kouchi. }\end{array}$ \\
\hline
\end{tabular}

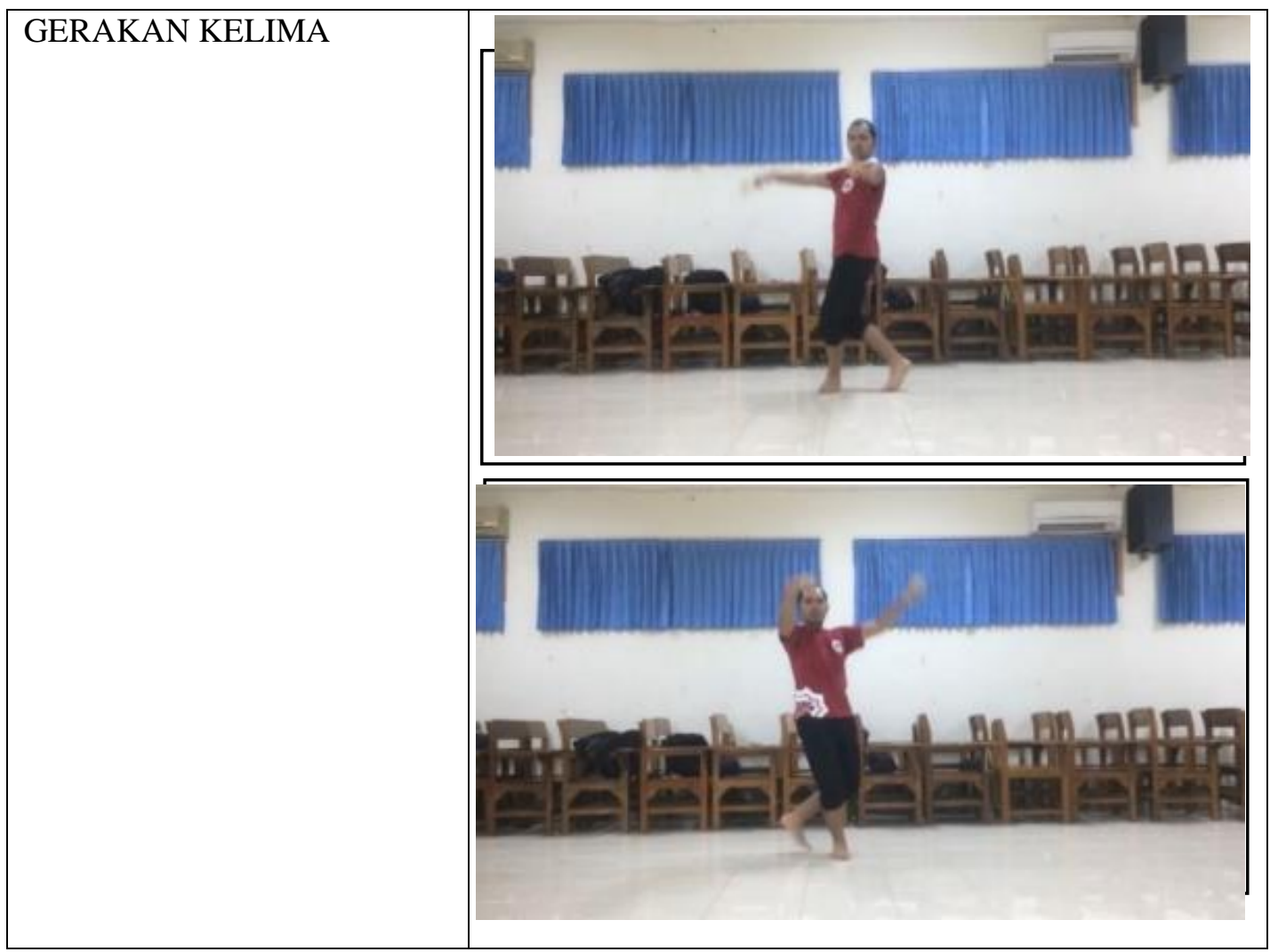




\begin{tabular}{|c|c|}
\hline Deksripsi Gerakan & 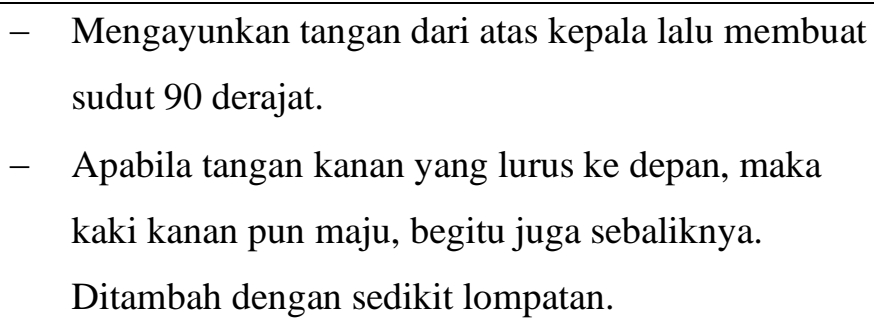 \\
\hline Makna Konotasi & $\begin{array}{l}\text { Gerakan ini menyambung dengan gerakan sebelumnya, } \\
\text { yang mengayunkan tangan ke kanan dan ke kiri. } \\
\text { Merujuk pada cerita rakyat yang menceritakan seorang } \\
\text { pria yang terlihat membeli hiasan rambut. }\end{array}$ \\
\hline
\end{tabular}

\subsection{Struktur Gerakan dan Makna Tarian Soran Bushi dari Yosakoi Soran}

Soran Bushi merupakan tarian yang berasal dari Hokkaido. Tarian ini berdurasi 3 menit 38 detik. Tarian soran bushi memiliki gerakan yang kuat dan jelas, ditambah dengan sorak-sorak penyemangat.

Berikut ini peneliti akan mendeskripsikan bentuk analisis semiotika Roland Barthes pada tarian soran bushi

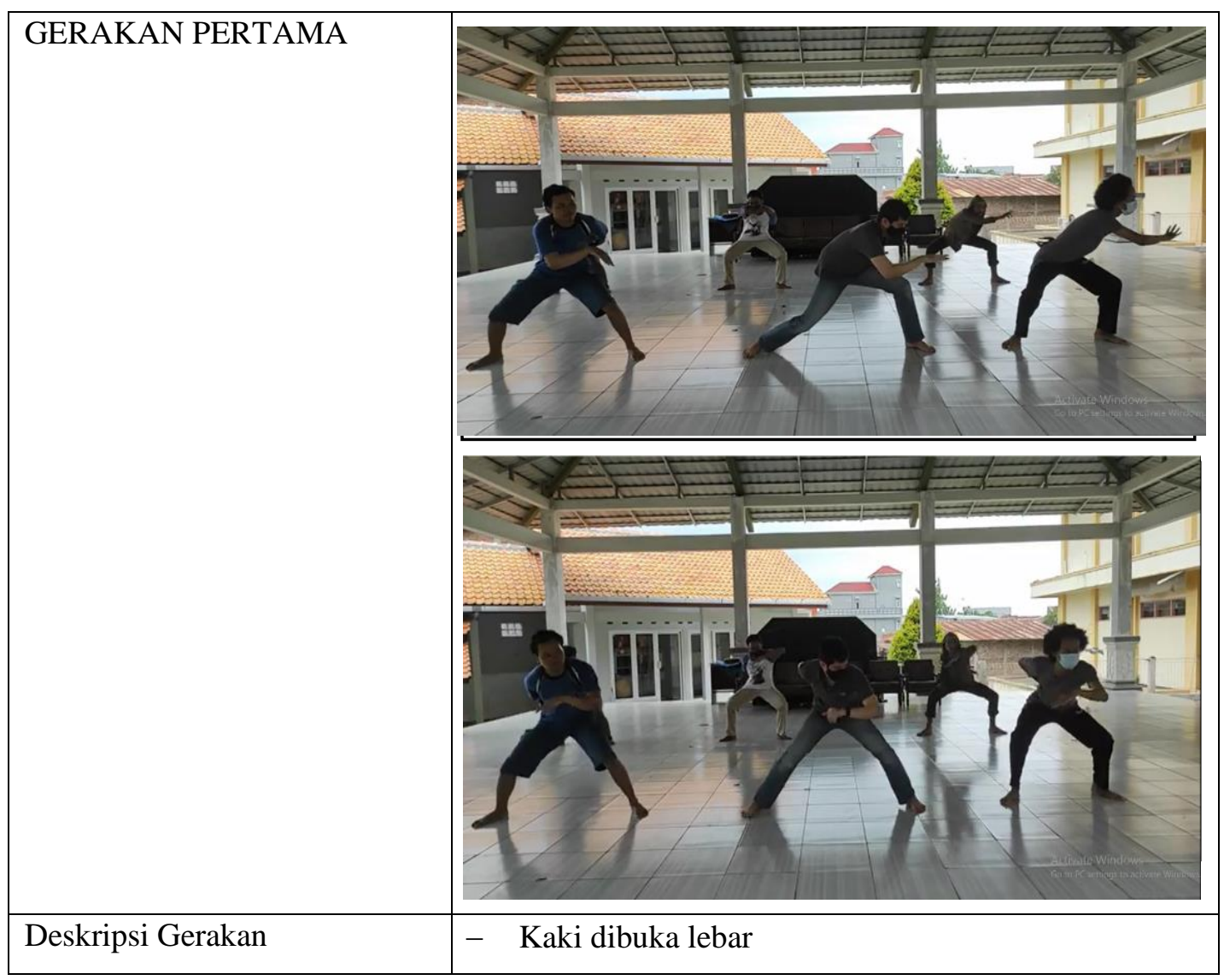




\begin{tabular}{|l|l|}
\hline \multirow{3}{*}{ Makna Konotasi } & $\begin{array}{l}- \\
\text { Satu tangan berada di belakang, dan tangan yang } \\
\text { satunya digerakan menyerupai ombak }\end{array}$ \\
$-\quad$ Gerakan tangan ini dilakukan secara bergantian \\
\hline $\begin{array}{l}\text { Gerakan kaki dan tangan bagaikan gerakan ombak yang } \\
\text { bergulir berulang-ulang. Bagaikan ombang yang } \\
\text { bergulung-gulung di lautan. } \\
\text { Hal ini menandai para nelayan untuk segera melaut, } \\
\text { menangkap ikan untuk menafkahi keluarganya. }\end{array}$ \\
\hline
\end{tabular}

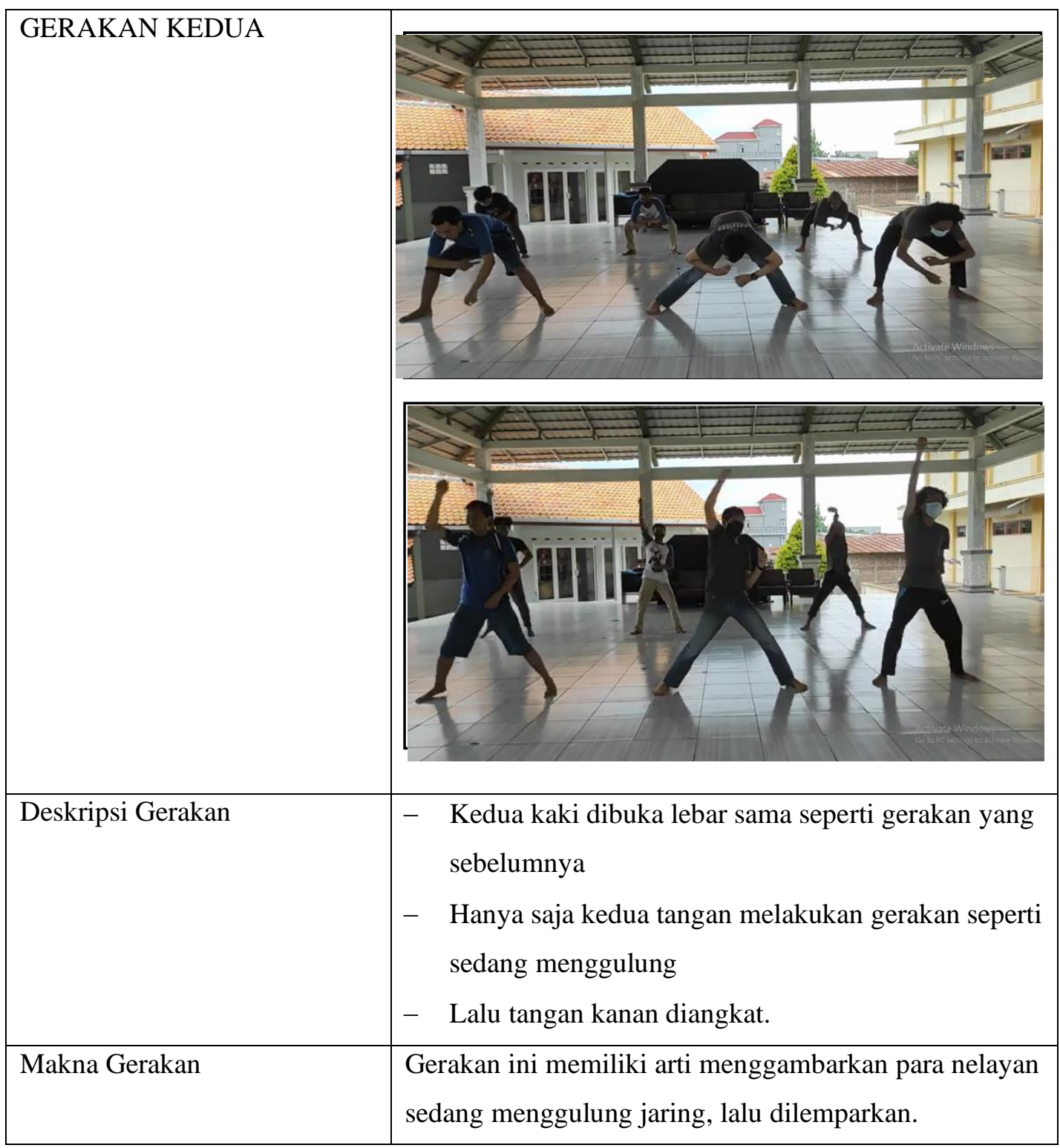




GERAKAN KETIGA

GERAKAN KEEMPAT




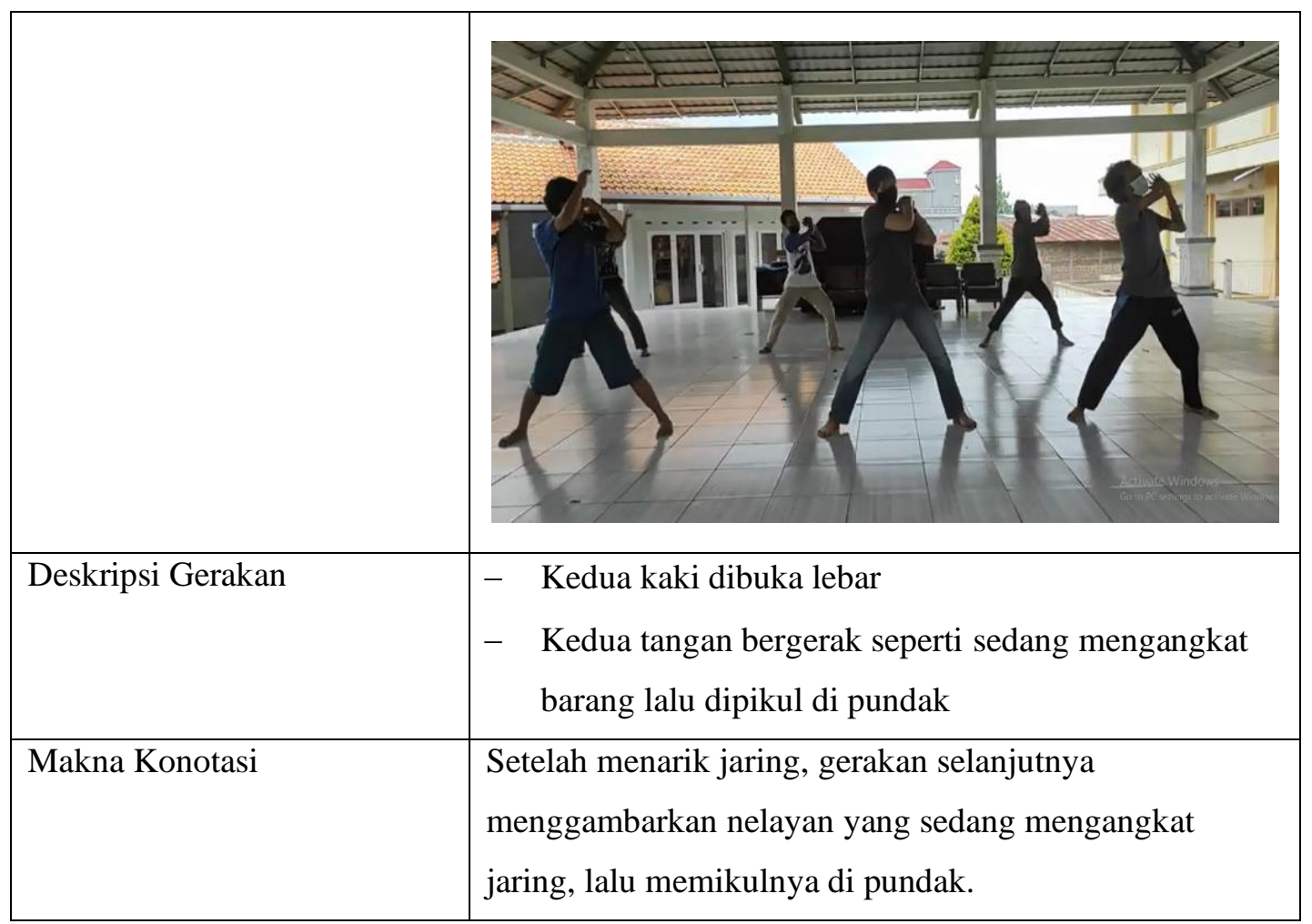

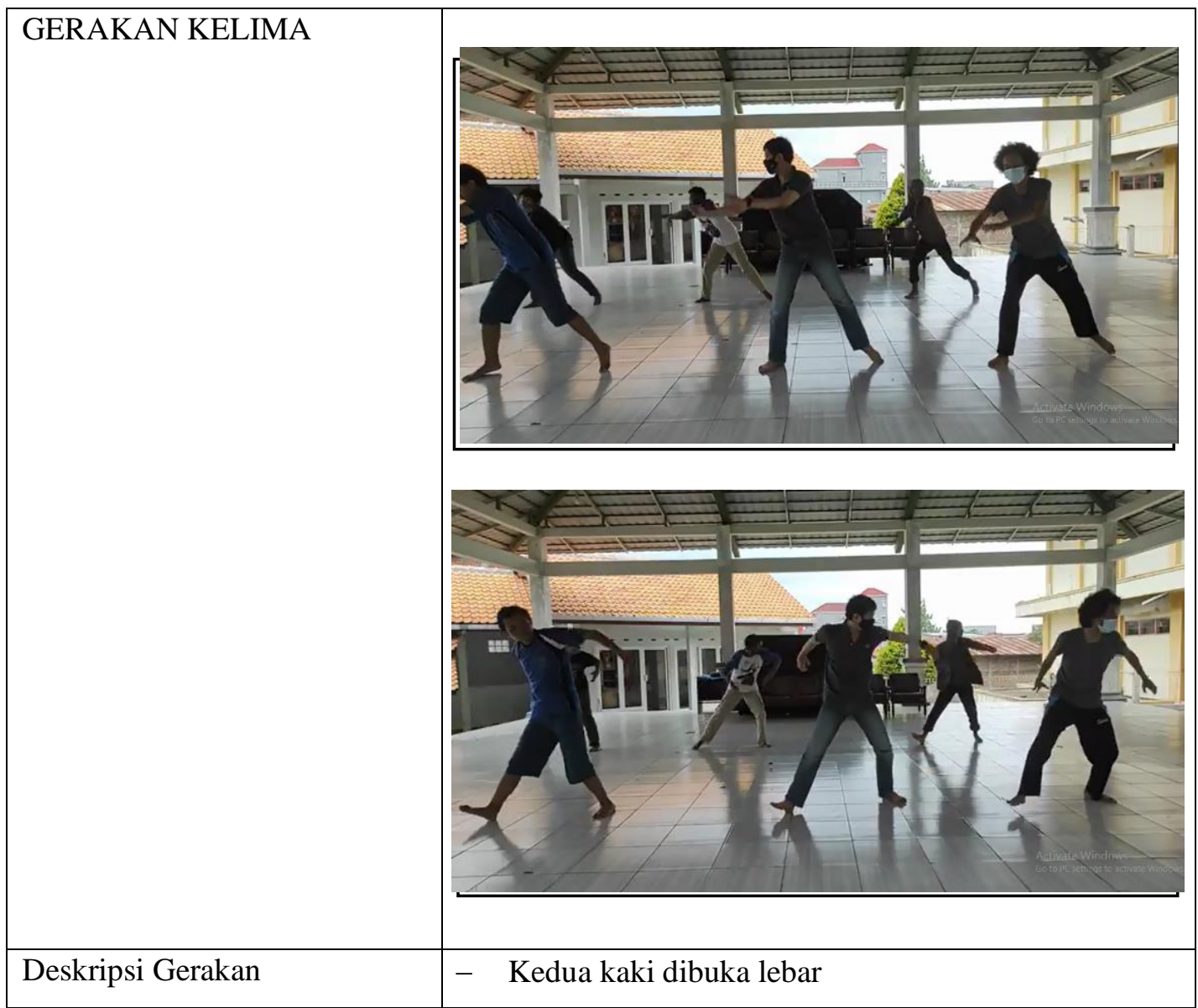




\begin{tabular}{|l|l|}
\hline & $\begin{array}{l}- \\
\text { Kedua tangan pada gerakan ini seperti sedang } \\
\text { menarik dan mendorong benda yang berat } \\
-\end{array}$ \\
\hline Makna Konotasi & $\begin{array}{l}\text { Gerakan ini menggambarkan para nelayan yang sedang } \\
\text { menarik dan mendorong perahu yang dipakai untuk } \\
\text { melaut }\end{array}$ \\
\hline
\end{tabular}

\begin{tabular}{|l|l|}
\hline GERAKAN KEENAM & \\
\hline Deskripsi Gerakan & $\begin{array}{l}\text { Kaki sejajar } \\
\text { Tangan kanan dikepalkan lalu diarahkan keatas, } \\
\text { tangan kiri tetap disamping badan, sambil bersorak } \\
\text { Hoi Hoi }\end{array}$ \\
\hline Makna Konotasi & $\begin{array}{l}\text { Menghentakkan kaki, dengan tangan kanan yang } \\
\text { mengepal keatas. } \\
\text { Ini menggambarkan para nelayan yang sedang } \\
\text { menyerukan teriakan teriakan untuk menambah } \\
\text { semangat mereka saat menangkap ikan }\end{array}$ \\
\hline
\end{tabular}




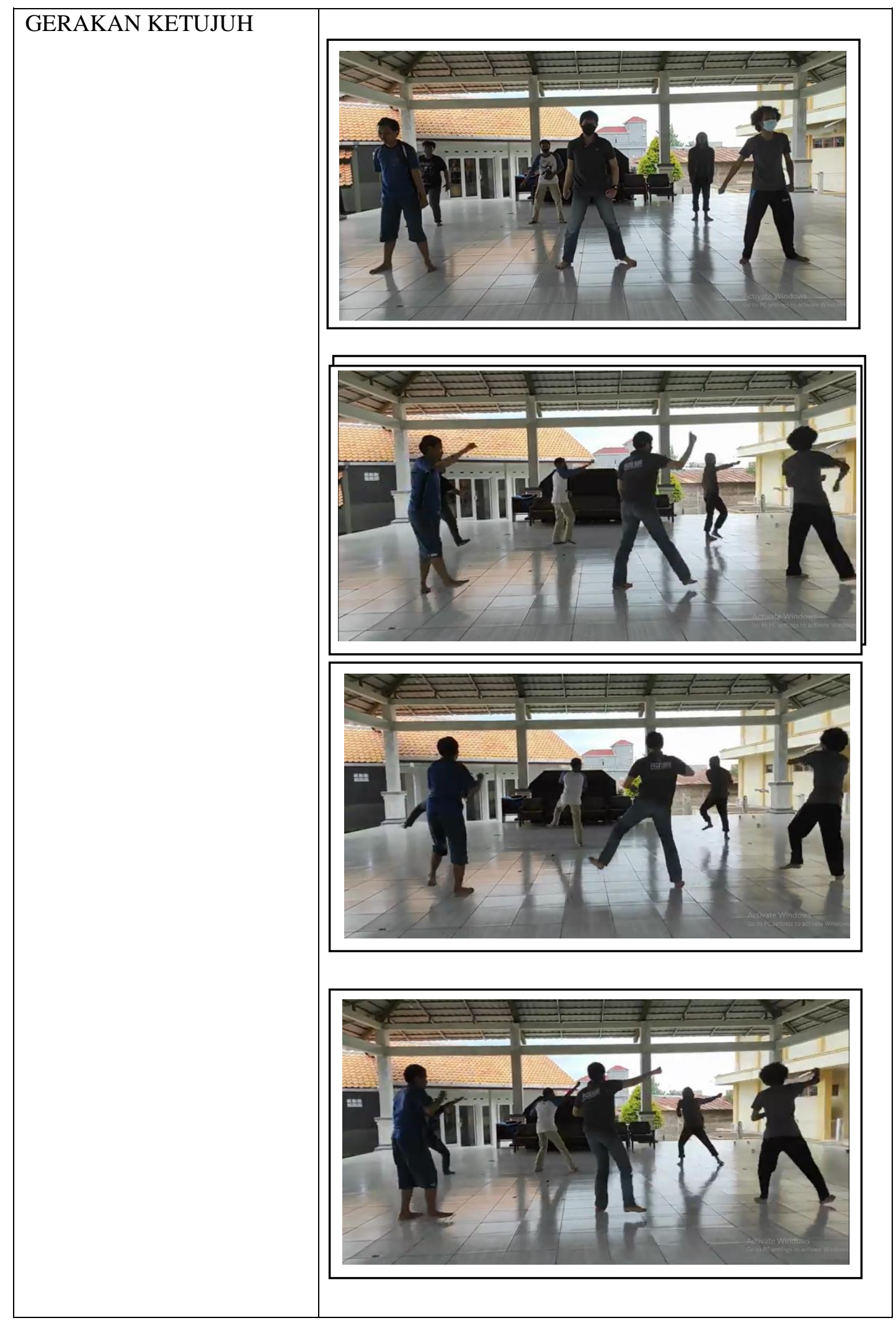




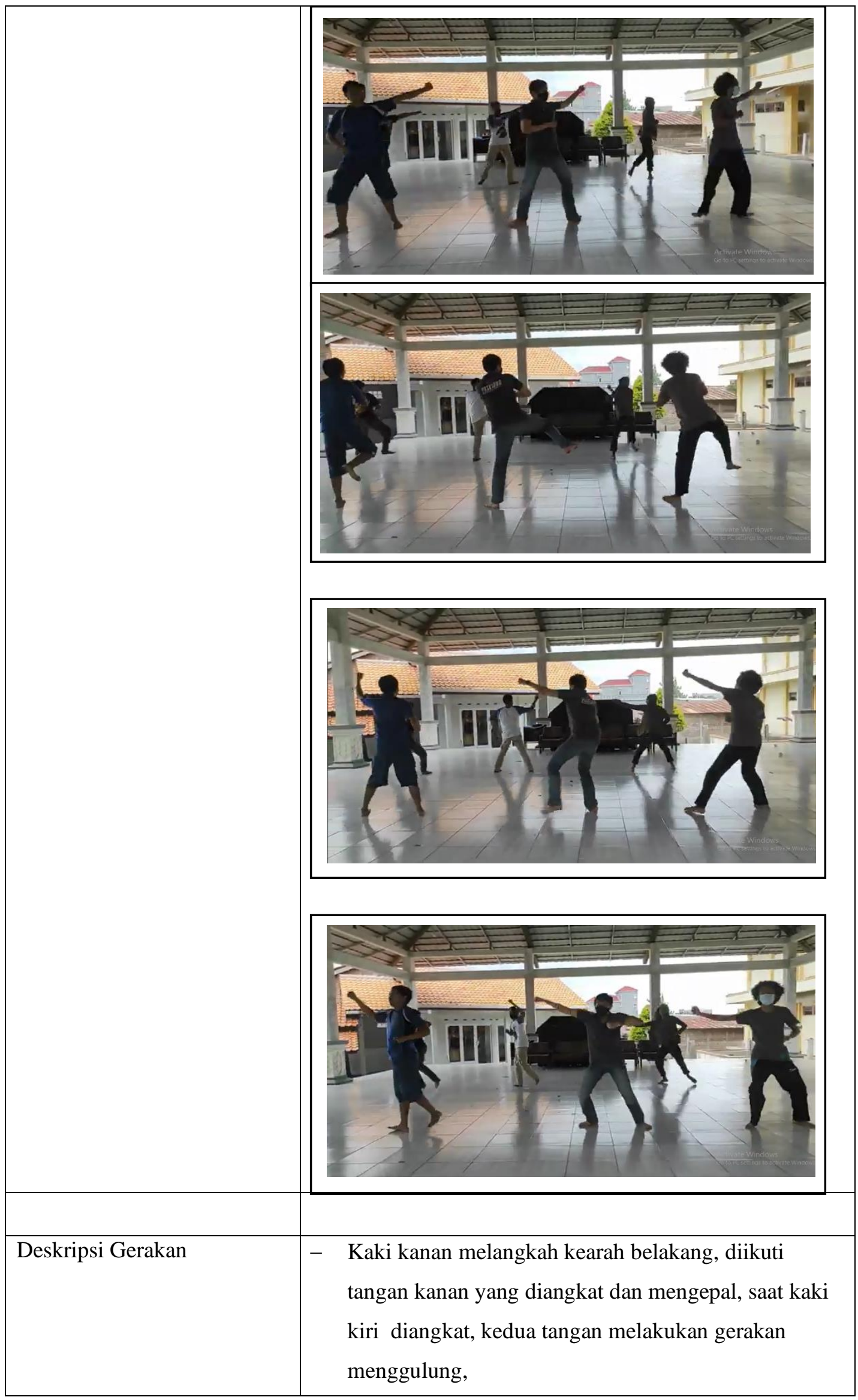




\begin{tabular}{|l|l|}
\hline & - Setelah itu kembali ke depan \\
& - Gerakan tersebut diulangi, berganti ke sebelah kiri \\
\hline Makna Konotasi & $\begin{array}{l}\text { Gerakan ini menggambarkan nelayan yang sedang } \\
\text { mengumpulkan jaring, lalu digulung, dan dilemparkan ke } \\
\text { arah yang lebih luas }\end{array}$ \\
\hline
\end{tabular}

\begin{tabular}{|l|l|}
\hline GERAKAN KEDELAPAN & Kedua kaki dibuka, kedua tangan direntangkan \\
\hline Makna Konotasi & Lalu bergerak ke kanan dan ke kiri, seperti kurang \\
\hline Deskripsi Gerakan & kergerak gerak terkena ombak \\
\hline
\end{tabular}

GERAKAN KESEMBILAN



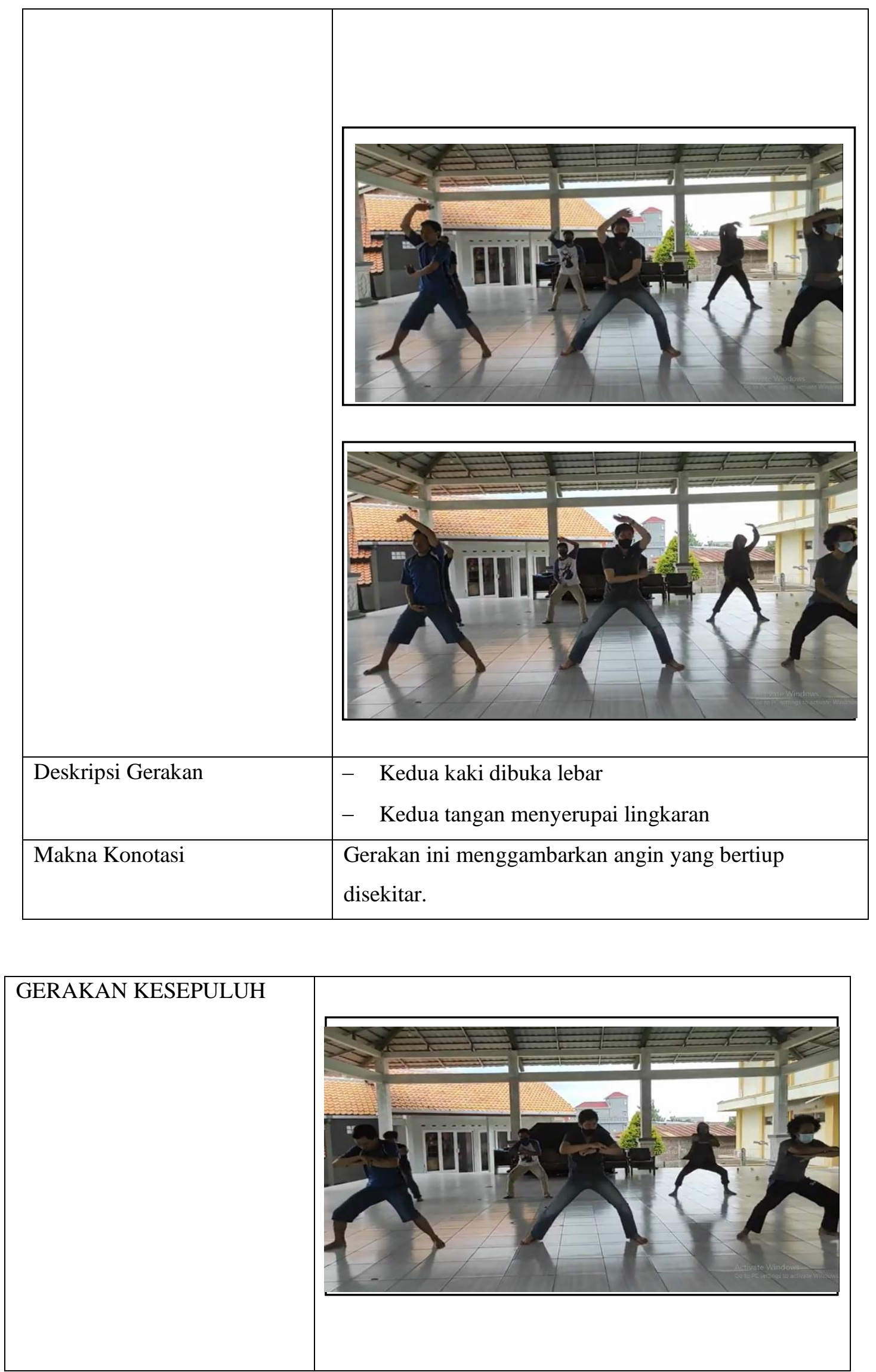

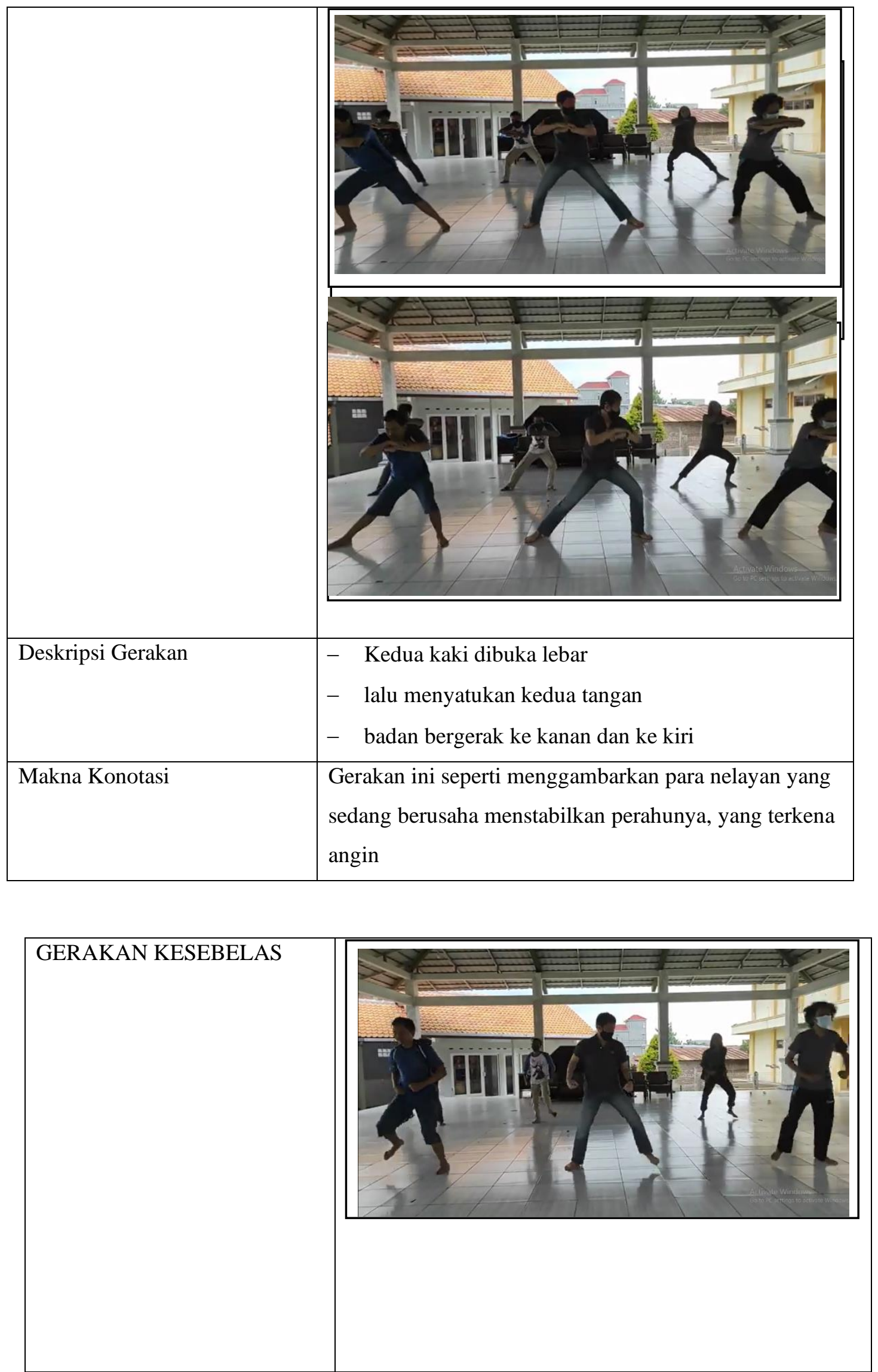

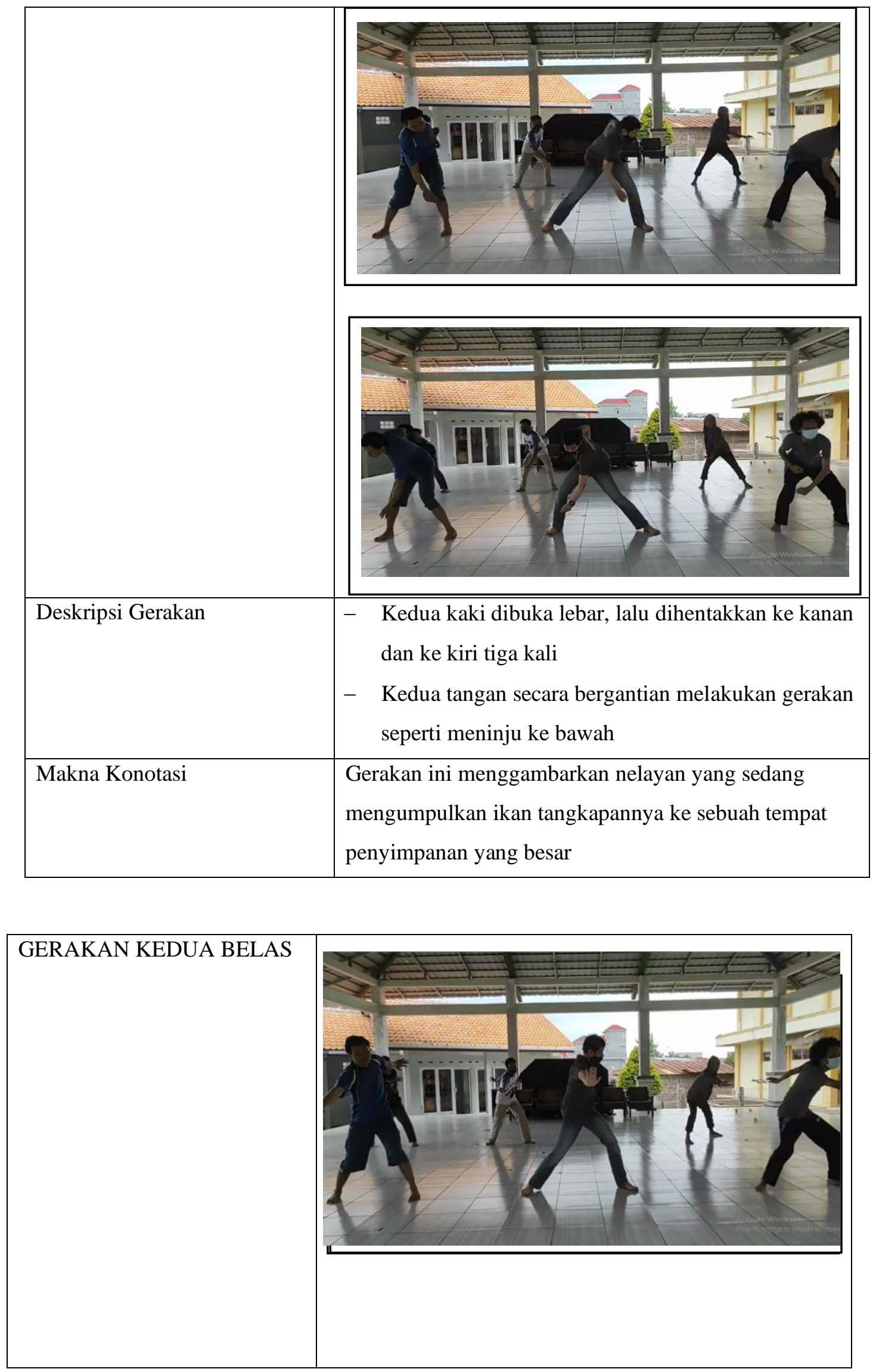


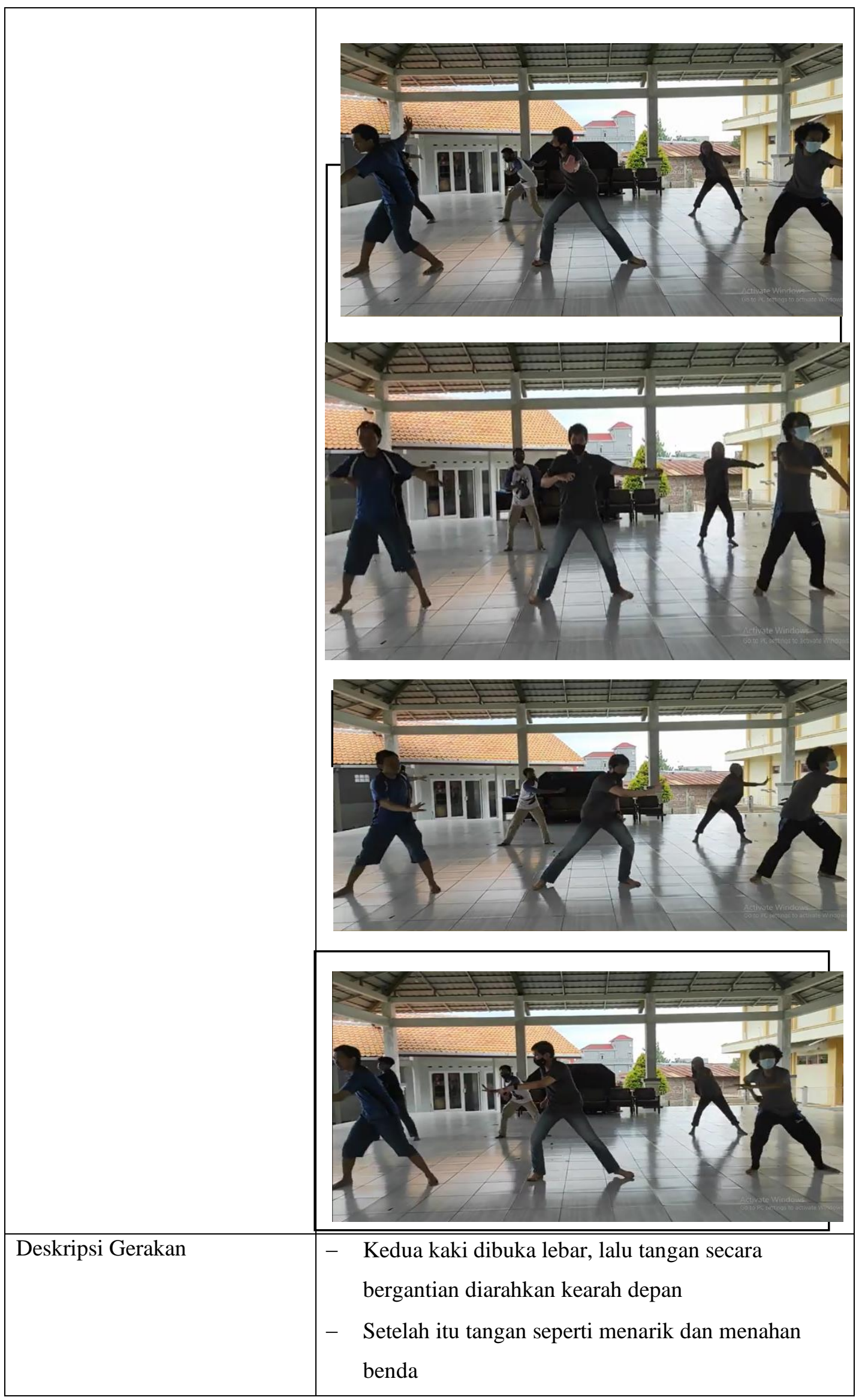




\begin{tabular}{|l|l|}
\hline Makna Konotasi & $\begin{array}{l}\text { Gerakan ini menggambarkan nelayan sedang } \\
\text { menepikan perahunya, mereka telah selesai menangkap } \\
\text { ikan dan akan meletakkan perahunya ke tempat semula. }\end{array}$ \\
\hline
\end{tabular}

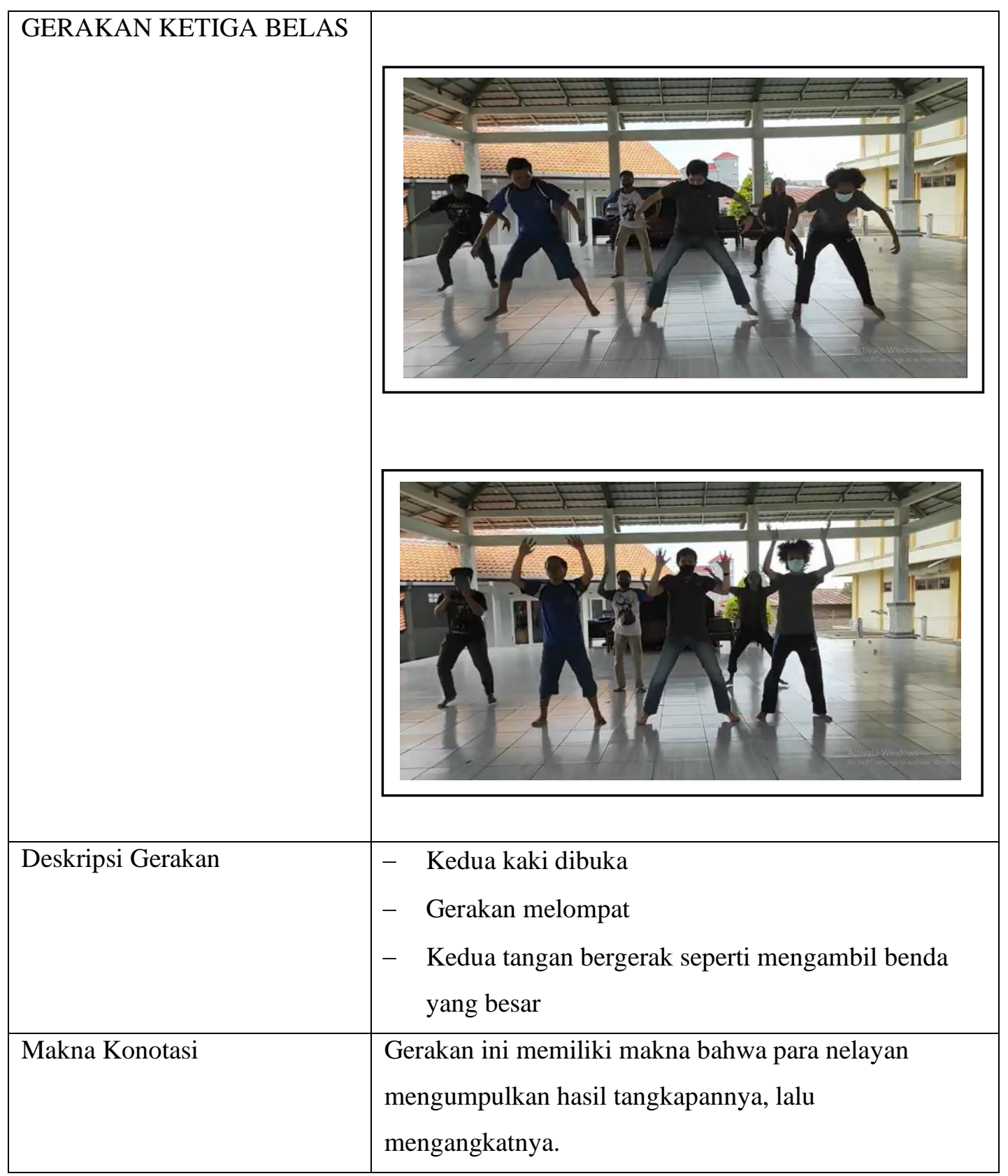




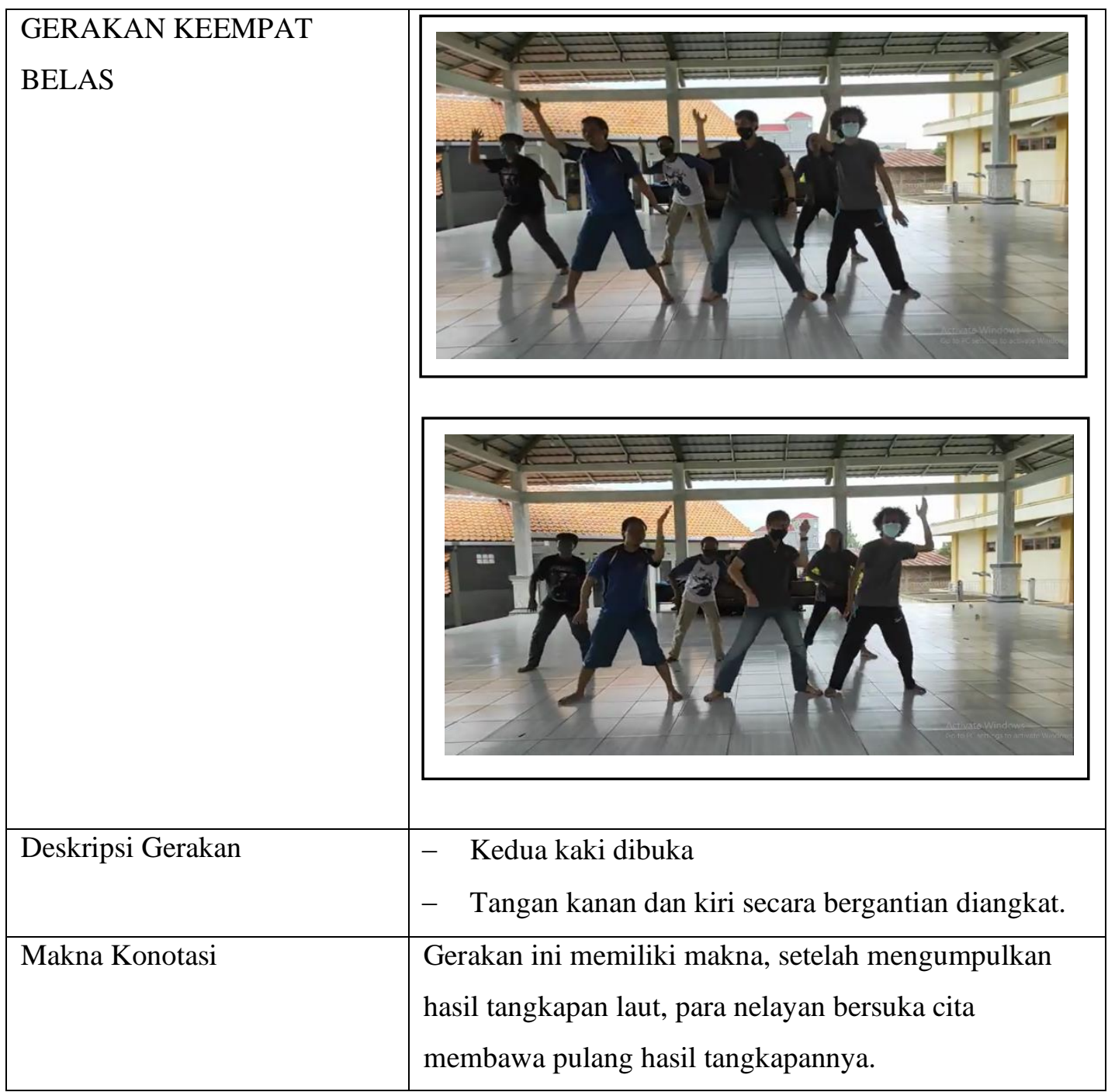

\section{Simpulan}

\subsection{Seicho Yosakoi}

Pada tari seicho yosakoi ditemukan 4 gerakan yang dilakukan secara berulang-ulang dengan struktur gerakan dan makna kesimpulan sebagai berikut :

\begin{tabular}{|l|l|}
\hline \multicolumn{1}{|c|}{ Nama Struktur Gerakan } & \multicolumn{1}{|c|}{ Makna } \\
\hline Gerakan 1 & Gerakan 1 bermakna para penari \\
meminta diberikan jalan kepada \\
penonton atau pengunjung yang ada. \\
\hline Gerakan 2 & Gerakan 2 bermakna mengajak atau \\
& memanggil orang-orang untuk \\
\hline
\end{tabular}




\begin{tabular}{|l|l|}
\hline Gerakan 3 & $\begin{array}{l}\text { berkumpul dan datang ke festival } \\
\text { yosakoi. }\end{array}$ \\
\hline Gerakan 4 & $\begin{array}{l}\text { Gerakan } 3 \text { bermakna semua orang } \\
\text { dapat bergabung menari bersama tanpa } \\
\text { batasan usia. }\end{array}$ \\
\hline Gerakan 5 & $\begin{array}{l}\text { Gerakan } 4 \text { bermakna padi yang } \\
\text { dergoyang, kedua tangan yang } \\
\text { kanan dan kiri ini menyerupai padi } \\
\text { yang bergerak tertiup angin. }\end{array}$ \\
\hline $\begin{array}{l}\text { Gerakan } 5 \text { ini merujuk pada cerita } \\
\text { rakyat tentang seorang pria yang } \\
\text { terlihat membeli hiasan rambut di } \\
\text { jembatan Harimaya, yang terkenal } \\
\text { sebagai tempat diselenggarakannya } \\
\text { festival kochi. }\end{array}$ \\
\hline
\end{tabular}

\subsection{Soran Bushi}

Pada tarian soran bushi ditemukan 14 gerakan dengan struktur dan makna sebagai berikut :

\begin{tabular}{|l|l|}
\hline \multicolumn{1}{|c|}{ Nama Struktur Gerakan } & \multicolumn{1}{|c|}{ Makna } \\
\hline Gerakan 1 & $\begin{array}{l}\text { Gerakan ini menggambarkan ombak } \\
\text { yang bergelombang di lautan }\end{array}$ \\
\hline Gerakan 2 & $\begin{array}{l}\text { Gerakan ini menggambarkan para } \\
\text { nelayan sedang menggulung jaring, } \\
\text { lalu dilemparkan }\end{array}$ \\
\hline Gerakan 3 & $\begin{array}{l}\text { Gerakan ini menggambarkan nelayan } \\
\text { yang sedang menarik jaring, setelah } \\
\text { melemparkan ke laut }\end{array}$ \\
\hline Gerakan 4 & $\begin{array}{l}\text { Gerakan ini menggambarkan nelayan } \\
\text { yang sedang mengangkat jaring, lalu } \\
\text { memikulnya di pundak }\end{array}$ \\
\hline
\end{tabular}




\begin{tabular}{|c|c|}
\hline Gerakan 5 & $\begin{array}{l}\text { Gerakan ini menggambarkan para } \\
\text { nelayan yang sedang menarik dan } \\
\text { mendorong perahu yang dipakai }\end{array}$ \\
\hline Gerakan 6 & $\begin{array}{l}\text { Ini menggambarkan para nelayan yang } \\
\text { sedang menyerukan teriakan teriakan } \\
\text { untuk menambah semangat mereka } \\
\text { menangkap ikan }\end{array}$ \\
\hline Gerakan 7 & $\begin{array}{l}\text { Gerakan ini menggambarkan nelayan } \\
\text { yang sedang mengumpulkan jaring, } \\
\text { lalu digulung, dan dilemparkan ke arah } \\
\text { yang lebih luas }\end{array}$ \\
\hline Gerakan 8 & $\begin{array}{l}\text { Gerakan ini menggambarkan kapal } \\
\text { nelayan yang bergerak gerak terkena } \\
\text { ombak }\end{array}$ \\
\hline Gerakan 9 & $\begin{array}{l}\text { Gerakan ini menggambarkan angin } \\
\text { yang bertiup disekitar. }\end{array}$ \\
\hline Gerakan 10 & $\begin{array}{l}\text { Geraka ini menggambarkan paa } \\
\text { nelayan yang berusaha menstabilkan } \\
\text { perahunya }\end{array}$ \\
\hline Gerakan 11 & $\begin{array}{l}\text { Gerakan ini menggambarkan nelayan } \\
\text { yang sedang menaruh ikan } \\
\text { tangkapannya di tempat penampungan } \\
\text { yang besar }\end{array}$ \\
\hline Gerakan 12 & $\begin{array}{l}\text { Gerakan ini menggambarkan para } \\
\text { nelayan sedang menepikan perahunya. }\end{array}$ \\
\hline Gerakan 13 & $\begin{array}{l}\text { Gerakan ini memiliki makna bahwa } \\
\text { para nelayan mengumpulkan hasil } \\
\text { tangkapannya, lalu mengangkatnya. }\end{array}$ \\
\hline Gerakan 14 & $\begin{array}{l}\text { Gerakan ini memiliki makna, setelah } \\
\text { mengumpulkan hasil tangkapan laut, } \\
\text { para nelayan bersuka cita membawa } \\
\text { pulang hasil tangkapannya. }\end{array}$ \\
\hline
\end{tabular}


Berdasarkan hasil analisis diatas, dapat disimpulkan bahwa tarian seicho dan soran memiliki makna konotasi sebagai berikut

1. Tarian seicho merupakan tarian yang berisi sebuah ajakan untuk beramai-ramai datang ke festival musim panas.

2. Tarian soran merupakan tarian yang berisi penggambaran kegiatan para nelayan saat menangkap ikan .

\section{Daftar Pustaka}

Anggito, Aldi. dan Setiawan, Johan. 2018. Metodologi Penelitian Kualitatif. Sukabumi: CV Jejak

Barthes, Roland. dan Heath, Stephen. 1997. image-music-text. Fontana Press.

Budiman, Kris. 2011. Semiotika Visual Konsep, Isu, dan Problema ikonitisitad. Yogyakarta: Jalasutra.

Endraswara, Suwardi. 2006. Metode, Teori, Teknik Penelitian Kebudayaan: Ideologi, Epistemologi, dan Aplikasi. Yogyakarta: Pustaka Widyatama.

Yunus, Hadi Sabari. 2010. Metodologi Penelitian Wilayah Kontemporer. Yogyakarta: Pustaka Pelajar

Masahiro, Iwai. 2006. Kore ga Kouchi no Yosakoi da! Igosso to Hachikintachi no Atsui Natsu. Tokyo. Japan

Baety, Nur. 2018. "Makna Tari Empat Etnis (Analisis Semiotika Roland Barthes)". Skripsi. Makassar: Fakultas Dakwah dan Komunikasi, Universitas Islam Negeri Alauddin Makassar.

Fachreza, Muhammad. 2017. "Perbedaan Ciri Khas pada Kochi Yosakoi dan Yosakoi Soran yang Muncul di Era Modern”. Skripsi. Jakarta: Fakultas Sastra, Universitas Darma Persada.

Hidayati, Ratih.K. 2016. "Makna Tari Bajidor Kahot Ditinjau Dari Semiotika Roland Barthes". PROMEDIA, Vol II No. 2, 2016, h. 64-82.

Kusuma, Putu.K.N. dan Nurhayati, Iis.K. 2017. "Analisis Semiotika Roland Barthes Pada Ritual Otonan Di Bali”. Jurnal Manajemen Komunikasi, Vol I No. 2-2017, h. 195-217.

Waldo, Verlinton. 2010. "Yosakoi Matsuri: Inovasi, Kesinambungan, dan Komersialisasi dalam Budaya”. Depok: Fakultas Ilmu Budaya, Universitas Indonesia. 